\title{
Investigation of protein content of synovial fluids with DSC in different arthritides
}

\author{
Norbert Wiegand ${ }^{1} \cdot$ Gábor Búcs $^{1} \cdot$ Árpád Dandé ${ }^{1}$ Dénes Lörinczy ${ }^{2}$
}

Received: 4 November 2018 / Accepted: 19 February 2019/Published online: 5 March 2019

(C) The Author(s) 2019

\begin{abstract}
In the case of joint diseases, as a result of the process induced by the pathophysiological factors, the small articular structures that have pilled result in a qualitative and quantitative modification of the composition of the synovial fluid (SF). The analysis of this fluid offers a unique opportunity to study the joint diseases. In our study, 28 cases of acute knee joint meniscus injuries, transient knee joint synovitis, or degenerative knee joint destruction were studied. Following the collection and storage of SF, removed on the basis of the sample collection protocol, they were denatured in a SETARAM Micro DSC-II calorimeter with a scanning rate $0.3 \mathrm{~K} \mathrm{~min}^{-1}$ in the $20-90{ }^{\circ} \mathrm{C}$ temperature range. $4-4$ samples from the "normal" SF batch were inoculated by two different strains of bacteria [Staphylococcus aureus and Staphylococcus epidermidis] with $10^{-3}$ colony-forming unit. Thermoanalytical changes of the proteins found in the SF were studied by a SETARAM Micro DSC-II, in the laboratory of the Biophysical Institute. The maximum denaturation temperature of the proteins being in the SF with different severity varied according to the criterion of the radiological scaling of osteoarthritis made by the Kellgren-Lawrence criterion. The decomposition of the scans showed the degree of the damage in case of SF as well as in the inoculated samples. Knowing the denaturing properties of temperature-dependent protein molecules in SF, DSC can be used to design and develop intraarticular lubricant additives that effectively enhance protein stability and contribute to a reduction in joint wear.
\end{abstract}

Keywords Differential scanning calorimeter · Bacterial strains $\cdot$ Human plasma/serum albumin · Osteoarthritis · Septic arthritis - Synovial fluid

\section{Introduction}

The protein concentration of SF as well as its intra-articular production and decrease in normal equilibrium is determined by synovial blood flow, plasma concentration, microvascular permeability, and lymph node separation [1]. It is known that the concentration of the synovial fluid in the protein is proportional to their molecular mass. In the event of injury and joint disease, such as osteoarthritis, progressive damage occurs, resulting in changes in the composition of the SF following the damage to the joint

Dénes Lőrinczy

denes.lorinczy@aok.pte.hu

1 Department of Traumatology and Hand Surgery, Clinical Centre, School of Medicine, University of Pécs, PécsSzigeti str. 12, 7624, Hungary

2 Department of Biophysics, School of Medicine, University of Pécs, PécsSzigeti str. 12, 7624, Hungary surface [2, 3]. Likewise, the change of SF protein concentration in the composition of SF varies with different etiologies. The study of synovial fluid is an important method for diagnosing and treating joint diseases.

In an earlier study, the average protein concentrations of osteoarthritis (OA) hip and knee are quite different in patients with healthy or rheumatoid arthritis [4]. The differential scanning calorimetry (DSC) is used as a diagnostic tool for detecting the concentration of altered thermal properties in a patient or injured condition.

Numerous studies have shown that microcalorimetry testing is a fast, well-used method for detecting septic joints [5-8] based on bacterial reproductive ability [8-10]. The aim of our study was to ensure accurate separation of the affected protein content determined by denaturation of SF, by determining the limit of the disease per group: the healthy joints, osteoarthritis, rheumatoid arthritis as well as septic arthritis. 


\section{Materials and methods}

In connection with the previous research activity in 2017, we began collecting samples, following a documented informed consent of the local ethics committee, performing patient information, which was prepared in accordance with the ethical guidelines of the 2003 Helsinki Declaration $[7,8]$.

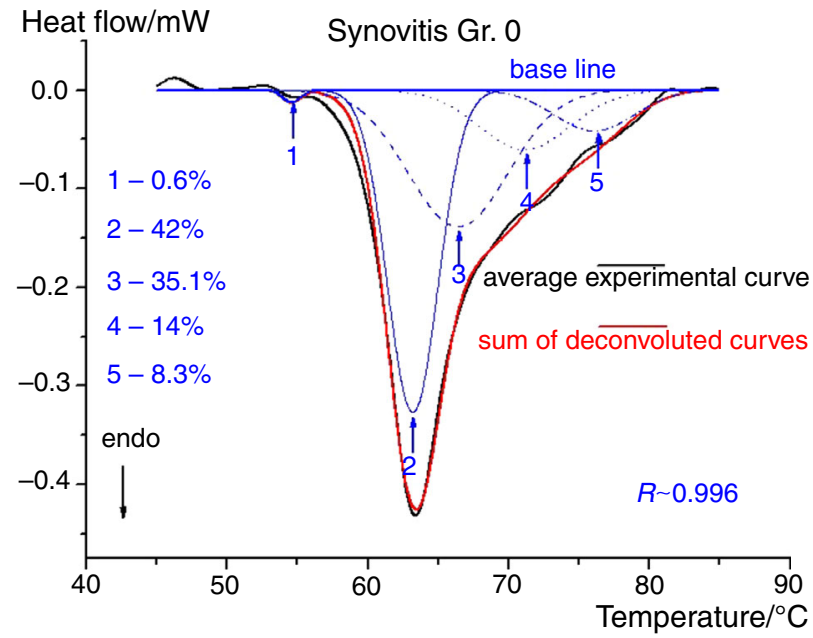

The numbered blue curves are the deconvolution Gaussians for the best fit $(R)$, together with their percentages

Fig. 1 Deconvoluted heat flow curve in case of control synovial fluid (average curve of four different measurements). We have tried to achieve best fitting $(R)$, but the centered $T_{\mathrm{m}}$ was albumin denaturation temperature. Symbols: numbers stand for deconvoluted compounds, percentages for contribution from the total calorimetric enthalpy, endotherm deflection downwards, average experimental curve solid black, cumulative curve red, and deconvoluted parts solid/dotted blue curves. (Color figure online)

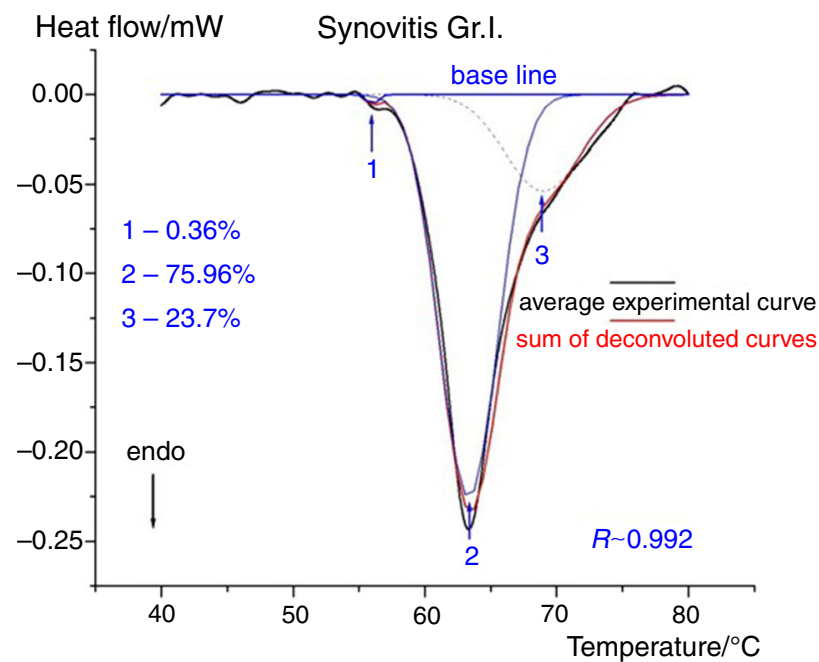

Human sample collection: Based on the selection criterion, acute knee joint meniscus injury, transient knee synovitis, or degenerative knee joint destructive treatment were included in the study. Human synovial samples were obtained at the Department of Traumatology and Hand Surgery under strict aseptic conditions during surgery, which would have been removed during the intervention. The collected synovial fluid was collected in a native sterile tube. The collected synovial fluid samples were then centrifuged at $3500 \mathrm{rpm}$ for $15 \mathrm{~min}$ and stored at $-70{ }^{\circ} \mathrm{C}$ for further processing when samples were gradually thawed to room temperature prior to use. Following the collection of the 28 samples, they were divided according to the degenerative condition of the knee joint determined according to the modified Kellgren-Lawrence classification [11].

Microbiological treatment: To simulate the septic infection, we have chosen two very aggressive bacteria.

Staphylococcus aureus (SA): Is a gram-positive bacterium; it is a member of the normal flora of the body and can grow in anaerobic circumstances too [12]. Despite a lot of research and development, until now, no vaccine for $S A$ can be found. About $20-30 \%$ of the human population is long-term carriers of $S A[13,14]$. It is one of the five most common causes of hospital-acquired infections (according to our previous result [15]) and is often the cause of wound infections following surgery. Around half a million patients in hospitals of the US contract a staphylococcal infection, mainly by $S A$ [16].

Staphylococcus epidermidis (SE): Is also a gram-positive bacterium. It is a part of the normal human flora (mainly skin flora). It is a facultative anaerobic bacteria. Although it is not usually pathogenic, it can be dangerous

The numbered blue curves are the deconvolution Gaussians for the best fit $(R)$, together with their percentages

Fig. 2 Denaturation curves for synovial fluids in the severity of arthritis in Gr. I. and II.. Other details are the same as in Fig. 1 

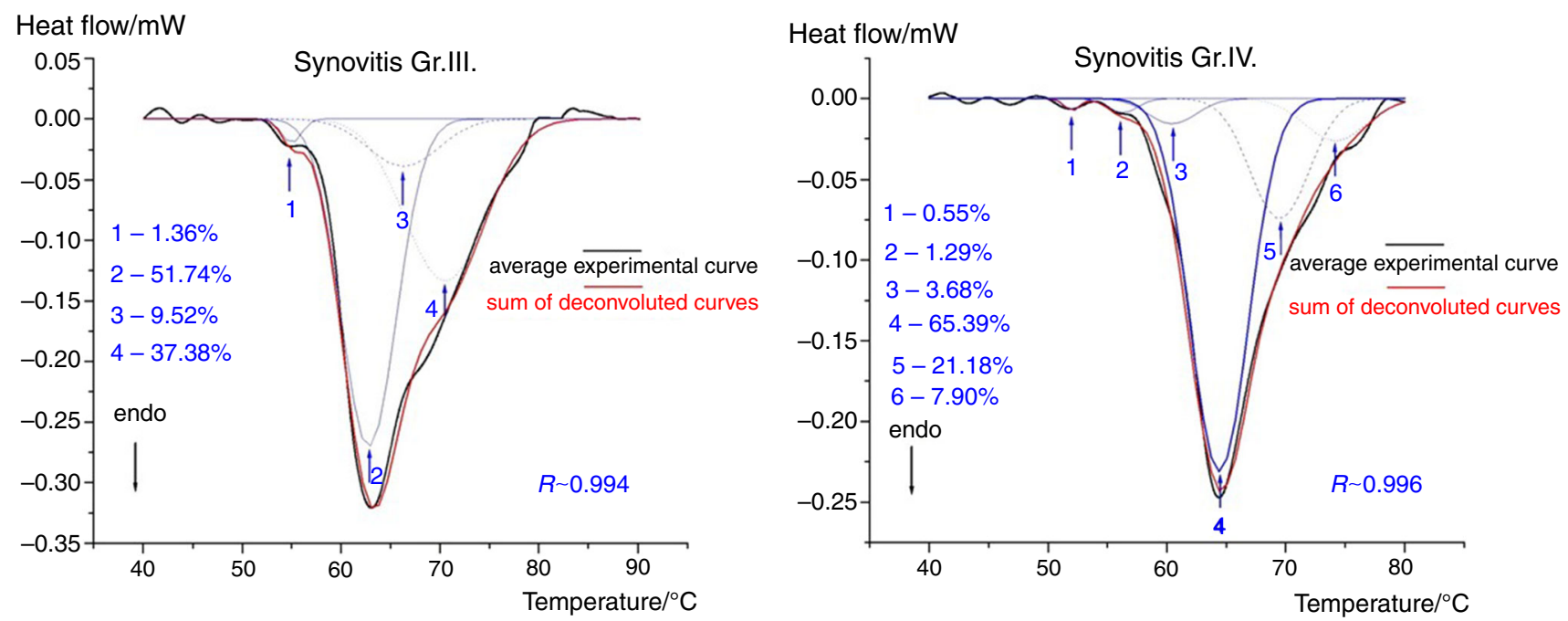

The numbered blue curves are the deconvolution Gaussians for the best fit $(R)$, together with their percentages

Fig. 3 Denaturation curves for synovial fluids in the severity of arthritis in Gr. III. and IV.. Other details are the same as in Fig. 1
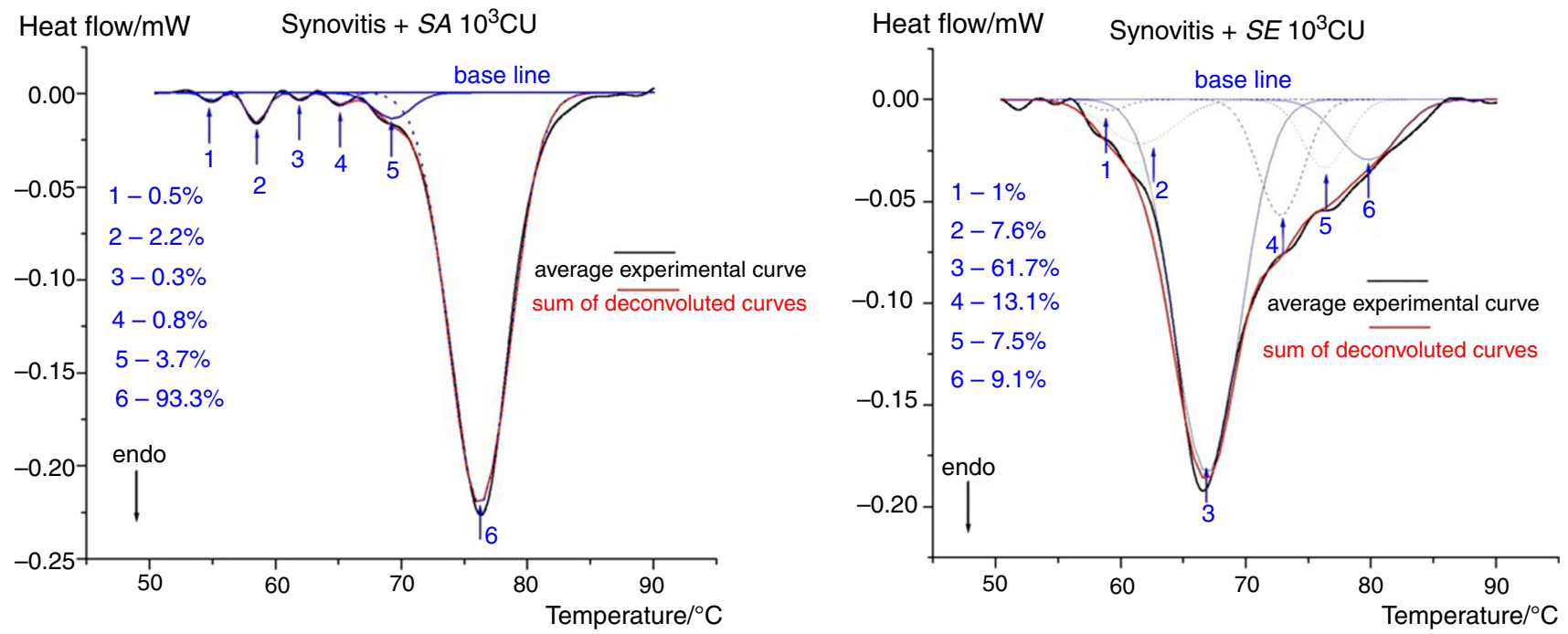

The numbered blue curves are the deconvolution Gaussians for the best fit $(R)$, together with their percentages

Fig. 4 Denaturation curves for synovial fluids infected with the most frequently occurring bacteria in the surgical practice. Other details are the same as in Fig. 1

for patients with compromised immune systems (causing infections in case of people with catheters or, e.g., implants). Because it is a part of the normal skin flora, during the laboratorial tests, it appears as a very often occurring contaminant of specimens sent to the diagnostic laboratory.

\section{DSC measurements}

Based on the experimental model we designed, the steps of the study were divided into two separate phases. The denaturation of the investigated synovial samples (4-4 samples in each stage) was examined in a liquid state after a careful sterile collection and preparation process in the DSC laboratory of the PTE Biophysical Institute with a SETARAM Micro DSC-II calorimeter. The average sample volume was $950 \mu \mathrm{L}$; the reference was normal saline solution.

In the first phase of the process, thermoanalytical analysis of the synovial liquid samples obtained during the various degrees of arthrosis was carried out in the 20-90 ${ }^{\circ} \mathrm{C}$ range with a $0.3 \mathrm{~K} \mathrm{~min}^{-1}$ heating rate. In the second test phase, two different $10^{-3} \mathrm{CFU} \mathrm{mL}{ }^{-1}$ bacterial strains (Staphylococcus aureus and Staphylococcus 
Table 1 Thermal parameters ( $T_{\mathrm{m}} \mathrm{s}$ melting temperatures of deconvoluted curves, $\Delta H$ total calorimetric enthalpy) of denatured different synovial fluids. The most characteristic values: $T_{2}$ stands for albumin and $T_{4}$ for immunoglobulins (other information in the text)

\begin{tabular}{|c|c|c|c|c|c|c|c|c|c|c|c|c|c|c|c|}
\hline \multirow[t]{2}{*}{ Synovial fluid } & \multicolumn{15}{|c|}{ Thermal parameters } \\
\hline & $\begin{array}{l}T_{1} / \\
{ }^{\circ} \mathrm{C}\end{array}$ & $\begin{array}{l}\Delta H / \\
\mathrm{J} \mathrm{g}^{-1}\end{array}$ & $\begin{array}{l}T_{2} / \\
{ }^{\circ} \mathrm{C}\end{array}$ & $\begin{array}{l}\Delta H / \\
\mathrm{J} \mathrm{g}^{-1}\end{array}$ & $\begin{array}{l}T_{3} / \\
{ }^{\circ} \mathrm{C}\end{array}$ & $\begin{array}{l}\Delta H / \\
\mathrm{J} \mathrm{g}^{-1}\end{array}$ & $\begin{array}{l}T_{4} / \\
{ }^{\circ} \mathrm{C}\end{array}$ & $\begin{array}{l}\Delta H / \\
\mathrm{J} \mathrm{g}^{-1}\end{array}$ & $\begin{array}{l}T_{5} / \\
{ }^{\circ} \mathrm{C}\end{array}$ & $\begin{array}{l}\Delta H / \\
\mathrm{J} \mathrm{g}^{-1}\end{array}$ & $\begin{array}{l}T_{6} / \\
{ }^{\circ} \mathrm{C}\end{array}$ & $\begin{array}{l}\Delta H / \\
\mathrm{J} \mathrm{g}^{-1}\end{array}$ & $\begin{array}{l}T_{7} / \\
{ }^{\circ} \mathrm{C}\end{array}$ & $\begin{array}{l}\Delta H / \\
\mathrm{J} \mathrm{g}^{-1}\end{array}$ & $\begin{array}{l}\text { Total } \Delta H / \\
\mathrm{J} \mathrm{g}^{-1}\end{array}$ \\
\hline Gr. 0. & 54.6 & 0.003 & 63.2 & 0.19 & 66.4 & 0.16 & 71.3 & 0.06 & & & 76.1 & 0.04 & & & 0.46 \\
\hline Gr. I. & & & 63.3 & 0.24 & & & 69.0 & 0.076 & & & & & & & 0.32 \\
\hline Gr. II. & & & 63.8 & 0.33 & & & 68.9 & 0.19 & & & & & & & 0.54 \\
\hline Gr. III. & & & 62.8 & 0.30 & 66.3 & 0.06 & 70.6 & 0.22 & & & & & & & 0.58 \\
\hline Gr. IV. & 56.3 & 0.013 & 60.4 & 0.015 & 64.4 & 0.26 & 69.5 & 0.085 & & & 74.2 & 0.03 & & & 0.40 \\
\hline Syn. + SA $10^{3} \mathrm{CFU}$ & 58.5 & 0.01 & & & 65.2 & 0.005 & 69.3 & 0.02 & & & 76.2 & 0.52 & & & 0.56 \\
\hline Syn. + SE $10^{3} \mathrm{CFU}$ & 59.0 & 0.006 & 61.5 & 0.05 & 66.9 & 0.37 & & & 72.8 & 0.09 & 76.3 & 0.05 & 79.8 & 0.055 & 0.60 \\
\hline
\end{tabular}

Bold values are out of average \pm s.d

epidermis) were added separately to the 4-4 samples. The mixtures were held at $37^{\circ} \mathrm{C}$ through $24 \mathrm{~h}$; after it, they were denatured in the $20-90{ }^{\circ} \mathrm{C}$ range with a heating rate equal to $0.3 \mathrm{~K} \mathrm{~min}^{-1}$.

\section{Results}

The thermal denaturation curves of synovial fluids in case of control and of various degree of arthrosis can be seen in Figs. 1-3. The curves are averages of four different sample runs; they are smoothed and baseline-corrected. Knowing that the synovial fluid contains different blood plasma proteins in high amount [2, 16-18], we have decomposed the scans with Gaussian functions to demonstrate the effect of severity of the disease (or infections, see Fig. 4) on the protein fragment. The "healthy" synovial fluid curve was similar to the healthy blood plasma scans [e.g., 19, 20]. In most cases, four well-resolved endotherms can be separated for the plasma compounds in the temperature range $50-76{ }^{\circ} \mathrm{C}(50-62-70-76)$ and at $82{ }^{\circ} \mathrm{C}$ [20]. According to Ferencz et al. [21], these transitions can be assigned to fibrinogen $\left(\sim 50{ }^{\circ} \mathrm{C}\right)$, albumin $\left(\sim 62^{\circ} \mathrm{C}\right)$, immunoglobulins $\left(\sim 70{ }^{\circ} \mathrm{C}\right), \operatorname{IgA}, \operatorname{IgG}$, and albumin $\left(\sim 76^{\circ} \mathrm{C}\right)$ as well as to transferrin and $\operatorname{IgG}\left(\sim 82^{\circ} \mathrm{C}\right)$. Of course, there are other contributors, but their concentration is rather small therefore their effect too. The deconvoluted thermal parameters can be found in Table 1 .

From figures and Table 1, it can be seen that very probably the albumin gives the biggest contribution to the calorimetric enthalpy (from the table are canceled those compounds which gave a contribution to the decomposition between 0.3 and $0.6 \%$ ). The average melting temperature $\left(T_{\mathrm{m}}\right)$ for albumin was higher $\left(63.2^{\circ} \mathrm{C}\right.$ for reference samples) than in blood plasma [19-21] and at Grade IV reached the maximum $\left(64.4^{\circ} \mathrm{C}\right)$. On the basis of data
[19-21], it seems that from albumin, very probably, we have more populations, one with 60.4 (structurally weaker part) and the others (more affected by arthritis) with 64.4 and $74.2^{\circ} \mathrm{C}$ melting temperatures. Generally, we can say that the enthalpy contribution in arthritic stages was greater compared with the control. The maximum was reached in Gr. II. stage. The melting in $\sim 69$ to $71{ }^{\circ} \mathrm{C}$ range is waited to characterize the immunoglobulins. The melting temperature is smaller in arthritic stages than in the control, but in Grade III, we observed an extreme high calorimetric enthalpy contribution.

After bacterial infection (Fig. 4), using $S A$, the albumin and immunoglubulin compounds give the highest calorimetric enthalpy and melting at $76.2^{\circ} \mathrm{C}$. $S E$ exhibited big albumin shift $\left(66.9\right.$ and $\left.76.3{ }^{\circ} \mathrm{C}\right)$ with transferrin and $\mathrm{IgG}$ contributions. These deviations from standard plasma values of course are influenced by other compounds of synovial fluid, but because of their small material content, it cannot be clearly separated.

\section{Discussion}

More than a decade since DSC measurements of patients have been focused in the researches, more and more authors confirmed importance and advantages of DSC data [22]. Briefly, these are the follows:

- Thermal parameters (e.g., $T_{\mathrm{m}}$ and $\Delta H$ ) of blood plasma or serum are significantly different in healthy individuals and in patients with various diseases, either in systematic inflammatory disorders or in tumorous diseases [23-27].

- DSC data show a strong correlation with clinical stages of different diseases [19, 25, 26, 28-34], and the experimental curves completely reflect the protein 
composition of the plasma or serum sample [27, 30-34].

- Changes in curves are the consequences not only of the quantitative changes of major plasma proteins, but of interactions of small molecules or peptides of these proteins also [27, 30, 32-34].

- The shape of DSC curves is very sensitive to conformation changes of proteins, to protein-protein or to ligand-protein interactions, to appearance of new proteins (e.g., paraproteins in cancerous diseases), or to influence of different medications to plasma proteins $[19,22-34]$.

As known, synovial fluid (SF) analysis is an important test for separation of joint infection from degenerative joint lesions based on rheumatological and immunological disorders. More recently, the qualitative and quantitative changes in SF can be studied by specific laboratory diagnostic procedures that, from point of view of certain biochemical and biophysical changes, provide useful information in clinical practice. Abnormal synovial fluid differs from the normal, not only in its composition but also in its appearance, sometimes confusing, denser or more fluid, but may vary significantly in color. The presence of crystals, white blood cells, red blood cells, other proteins, or microorganisms can be demonstrated in the composition of the synovial liquid of the confused appearance of the color altering from the average.

The SF, a biological compound lubricant of the joints, which contains blood plasma proteins (albu$\min \sim 11 \mathrm{mg} \mathrm{mL}^{-1}$ and different types of globulin $\left.\sim 7 \mathrm{mg} \mathrm{mL}^{-1}\right), \quad$ lipids, hyaluronic acid $\left(\sim 3 \mathrm{mg} \mathrm{mL}^{-1}\right)$, proteoglycan, and many small molecules, such as glucose, salts, and carbon dioxide $[2,15,16]$. Hyaluronic acid (HA) is synthesized in the synovial fluid by synoviolitis, a high molecular weight polysaccharide whose main feature in the joint is that it is able to bind a lot of water, thereby providing the viscosity of the joints as a natural moisturizing ingredient. It lowers the friction on the surface of the cartilage of the joints. In the case of swollen diseases, it is possible to inject directly into the joints to reduce pain and prevent further abrasion of the cartilage.

HA besides its biomechanical and biochemical properties, it has countless physiological functions, a promising, disease-specific bioindicator of inflammatory processes $[34,35]$. The molecular mass of HA in the human body is typically within the range of $10^{5}-10^{7} \mathrm{Da}$, which decides the function of the molecule. For example, high molecular mass HA ( $>1000 \mathrm{kDa})$ exhibits high viscosity, antiinflammatory, and immunosuppressive properties [35, 36], while low molecular mass HA $(<500 \mathrm{kDa})$ can cause the release of antiinflammatory cytokines [35-38].
In recent years, the need for a rapid and reliable immunohistochemical procedure has been growing in the interest of targeted therapeutic treatment of joint and prosthesis infections. A Philadelphian research group, Deirmengian and Parvizi, isolated 16 peptides from synovial fluid, which could play a role in detecting infection. Among these, alpha defensin $(\alpha \mathrm{D})$ proved to be the most promising, so this protein was suggested for the further investigation in the diagnosis of peripheral arthritis [39]. In practice, Synovasure ${ }^{\circledR}$ Alpha Defensin Test is available for this purpose, which detects $\alpha \mathrm{D}$ positivity after $10 \mathrm{~min}$ [40].

Disconnected small joint structures result in a qualitative and quantitative modification of the composition of the SF, in which the analysis of the components provides a unique opportunity to study the joint diseases. According to a previous study, in osteoarthritis (OA) compared with the healthy joint, we can find the most excreted protein in the SF [41]. The integrity of the SF protein-rich lubricant composition depends to a large extent on the temperature in the zone of contact-pressure exposure.

In the case of overloaded joints, uneven abrasion conditions and surface replacement implants, the increased temperature increases protein degradation and accelerates abrasion [42]. The most common protein in SF is human serum albumin (HSA), which plays an important role in the lubrication of the cartilage, thereby protecting the joint cartilage surface from the abrasion [43]. The model, investigated under our experimental conditions by differential scanning calorimetry (DSC), proved to be a wellused method in case of healthy, degenerative, and contagious arthritis, for the reproducible detection and quantification of temperature-dependent denaturation of protein content in SF.

Previous studies have shown that by qualitative and quantitative modifications of albumin composition, structural destabilization will appear, or by applying certain amino acids, we can achieve stabilization of albumin structures [44-49]. According to our recent work, it can be seen that the albumin is a very sensitive monitor of the effect of arthritis and bacterial infections of synovial fluid. Knowing the denaturation properties of temperature-dependent protein molecules in SF (mainly albumin and different globulins), DSC can be used in the design and development of intra-articular lubricant additives that effectively enhance the heat stability of proteins, by which can be influenced the process of abrasion of the joints.

\section{Conclusions}

DSC has proved to be such a testing method to investigate the changes of the proteins that make up the SF, which is an outstanding test procedure for the development of intra- 
articular additives. To develop multiple workplaces, DSC measurements should be performed for simultaneous control of different antibiotics in infected SF samples. In those sample holders where there is no proliferation of bacteria, antibiotics should be used for the treatment of patient.

Acknowledgements Open access funding provided by University of Pécs (PTE). This work was supported by Grant OTKA CO-272 (for D. Lörinczy). The authors express their thanks to Prof. Béla Kocsis (University of Pécs, Medical School, Department of Medical Microbiology and Immunology) for providing the bacteria to the experiments.

Open Access This article is distributed under the terms of the Creative Commons Attribution 4.0 International License (http://creative commons.org/licenses/by/4.0/), which permits unrestricted use, distribution, and reproduction in any medium, provided you give appropriate credit to the original author(s) and the source, provide a link to the Creative Commons license, and indicate if changes were made.

\section{References}

1. Goldring SR, Goldring MB. Biology of the normal joint. In: Firestein GS, Budd RC, Gabriel SE, McInnes IB, O'Dell JR, editors. Kelley and Firestein's textbook of rheumatology, chapter 1. 10th ed. Amsterdam: Elsevier; 2017. p. 1.e4-19.e4. ISBN 9780323316965.

2. Briere LAK, Brandt JM, Medley JB. Measurement of protein denaturation in human synovial fluid and its analogs using differential scanning calorimetry. J Therm Anal Calorim. 2010;102:99-106.

3. Mazzucco D, Scott R, Spector M. Composition of joint fluid in patients undergoing total knee replacement and revision arthroplasty: correlation with flow properties. Biomaterials. 2004;25(18):4433-45.

4. Brandt JM, Brière LK, Marr J, MacDonald SJ, Bourne RB, Medley JB. Biochemical comparisons of osteoarthritic human synovial fluid with calf sera used in knee simulator wear testing. J Biomed Mater Res A. 2010;94(3):961-71.

5. Borens O, Yusuf E, Steinrücken J, Trampuz A. Accurate and early diagnosis of orthopedic device-related infection by microbial heat production and sonication. $\mathrm{J}$ Orthop Res. 2013;31(11):1700-3.

6. Yusuf E, Hugle T, Daikeler T, Voide C, Borens O, Trampuz A. The potential use of microcalorimetry in rapid differentiation between septic arthritis and other causes of arthritis. Eur J Clin Microbiol Infect Dis. 2015;34(3):461-5.

7. Dandé Á, Nöt LG, Wiegand N, Kocsis B, Lőrinczy D. DSC analysis of human synovial fluid samples in the diagnostics of non-septic and septic arthritis. J Thermal Anal Calorim. 2017;130(3):1249-53.

8. Dandé Á, Nöt LG, Bücs G, Wiegand N, Kocsis B, Lőrinczy D. Examination of typical bacterial strains in septic arthritis by isoperibol calorimeter. $\mathrm{J}$ Thermal Anal Calorim. 2018;131(3):204148.

9. Trampuz A, Salzmann S, Antheaume J, Daniels AU. Microcalorimetry: a novel method for detection of microbial contamination in platelet products. Transfusion. 2007;47(9):1643-50.

10. Braissant O, Wirz D, Göpfert B, Daniels AU. Use of isothermal microcalorimetry to monitor microbial activities. FEMS Microbiol Lett. 2010;303(1):1-8.
11. Guermazi A, Hunter DJ, Roemer FW. Plain radiography and magnetic resonance imaging diagnostics in osteoarthritis: validated staging and scoring. J Bone Joint Surg Am. 2009;91(Suppl 1):54-62.

12. Masalha M, Borovok I, Schreiber R, Aharonowitz Y, Cohen G. Analysis of transcription of the Staphylococcus aureus aerobic class Ib and anaerobic class III ribonucleotide reductase genes in response to oxygen. J Bacteriol. 2001;183(24):7260-72.

13. Kluytmans J, van Belkum A, Verbrugh H. Nasal carriage of Staphylococcus aureus: epidemiology, underlying mechanisms, and associated risks. Clin Microbiol Rev. 1997;10(3):505-20.

14. Tong SY, Davis JS, Eichenberger E, Holland TL, Fowler VG. Staphylococcus aureus infections: epidemiology, pathophysiology, clinical manifestations, and management. Clin Microbiol Rev. 2015;28(3):603-61.

15. Dandé Á, Nöt LG, Bücs G, Wiegand N, Kocsis B, Lőrinczy D. Examination of typical bacterial strains in septic arthritis by isoperibol calorimeter. $\mathrm{J}$ Thermal Anal Calorim. 2018;131(3):2041-8.

16. Oates KM, Krause WE, Jones RL, Colby RH. Rheopexy of synovial fluid and protein aggregation. J R Soc Interface. 2006;3(6):167-74.

17. Blewis ME, Nugent-Derfus GE, Schmidt TA, Schumacher BL, Sah RL. A model of synovial fluid lubricant composition in normal and injured joints. Eur Cell Mater. 2007;6(13):26-39.

18. Garbett NC, Mekmaysy C, Helm CV, Jenson AB, Chaires JB. Differential scanning calorimetry of blood plasma for clinical diagnosis and monitoring. Exp Mol Pathol. 2009;86:186-91.

19. Todinova S, Krumova S, Kurtev P, Dimitrov V, Djongov L, Dudunkov Z, Stefka G, Taneva SG. Calorimetry-based profiling of blood plasma from colorectal cancer patients. BBA. 2012;1820:1879-85.

20. Garbett NC, Miller JJ, Jenson AB, Chaires JB. Calorimetry outside the box: a new window into the plasma proteome. Biophys $\mathrm{J}$. 2008;94:1377-83.

21. Ferencz A, Fekecs T, Lörinczy D. Differential scanning calorimetry, as a new method to monitor human plasma in melanoma patients with regional limph node or distal metastases. In: Xi Y, editor. Skin cancer: book 2, chp. 6. Rijeka: Intech Publischer; 2011. p. 141-51. ISBN 979-953-307-661-3.

22. Garbett NC, Miller JJ, Jenson AB, Chaires JB. Calorimetric analysis of the plasma proteome. Semin Nephrol. 2007;27:621-6.

23. Spink CH. Differential scanning calorimetry. Methods Cell Biol. 2008;84:115-41.

24. Zapf I, Fekecs T, Ferencz A, Tizedes G, Pavlovics G, Kálmán E, Lörinczy D. DSC analysis of human plasma in breast cancer patients. Thermochim Acta. 2011;524:88-91.

25. Zapf I, Moezzi M, Fekecs T, Nedvig K, Lőrinczy D, Ferencz A. Influence of oxidative injury and monitoring of blood plasma by DSC on breast cancer patients. $J$ Therm Anal Calorim. 2016;123:2029-35.

26. Michnik A, Drzazga Z. Thermal denaturation of mixtures of human serum proteins DSC study. J Therm Anal Calorim. 2010;101:513-8.

27. Moezzi M, Fekecs T, Zapf I, Ferencz A, Lőrinczy D. Differential scanning calorimetry (DSC) analysis of human plasma in different psoriasis stages. J Therm Anal Calorim. 2013;111:1801-4.

28. Fekecs T, Zapf I, Ferencz A, Lőrinczy D. Differential scanning calorimetry (DSC) analysis of human plasma in melanoma patients with or without regional lymph node metastases. J Therm Anal Calorim. 2012;108:149-52.

29. Michnik A. Blood plasma, serum and serum proteins microcalorimetric studies aimed at diagnosis support. In: Lörinczy D, editor. Thermal analysis in medical application. Budapest: Akadémiai Kiadó; 2011. p. 171-90. 
30. Garbett NC, Chaires JB. Thermodynamic studies for drug design and screening. Expert Opin Drug Discov. 2012;7:299-314.

31. Garbett NC, Mekmaysy CS, DeLeeuw L, Chaires JB. Clinical application of plasma thermograms: utility, practical approaches and considerations. Methods. 2015;76:41-50.

32. Vega S, Garcia-Gonzalez MA, Lanas A, Velazquez-Campoy A, Abian A. Deconvolution analysis for classifying gastric adenocarcinoma patients based on differential scanning calorimetry serum thermograms. Sci Rep. 2015;5:7988.

33. Garbett NC, Merchant ML, Helm CW, Jenson AB, Klein JB, Chaires JB. Detection of cervical cancer biomarker patterns in blood plasma and urine by differential scanning calorimetry and mass spectrometry. PLoS ONE. 2014;9:e84710.

34. Neuman MG, Cohen LB, Nanau RM. Hyaluronic acid as a noninvasive biomarker of liver fibrosis. Clin Biochem. 2016;49:302-15.

35. Rivas F, Zahid OK, Reesink HL, Peal BT, Nixon AJ, DeAngelis PL, Skardal A, Rahbar E, Hall AR. Label-free analysis of physiological hyaluronan size distributi on with a solid state nanopore sensor. Nat Commun. 2018;9(1):1037.

36. Nakamura $\mathrm{K}$, Yokohama S, Yoneda M, Okamoto S, Tamaki Y, Ito T, Okada M, Aso K, Makino I. High, but not low, molecular weight hyaluronan prevents T-cell-mediated liver injury by reducing proinflammatory cytokines in mice. J Gastroenterol. 2004;39:346-54.

37. Noble PW, Lake FR, Henson PM, Riches DW. Hyaluronate activation of CD44 induces insulin-like growth factor-1 expression by a tumor necrosis factor-alpha-dependent mechanism in murine macrophages. J Clin Invest. 1993;91:2368-77.

38. Rayahin JE, Buhrman JS, Zhang Y, Koh TJ, Gemeinhart RA. High and low molecular weight hyaluronic acid differentially influence macrophage activation. ACS Biomater Sci Eng. 2015;1:481-93.

39. Deirmengian C, Kardos K, Kilmartin P, Cameron A, Schiller K, Parvizi J. Diagnosing periprosthetic joint infection: has the era of the biomarker arrived? Clin Orthop Relat Res. 2014;472(11):3254-62.

40. Bonanzinga T, Zahar A, Dutsch M, Lausmann C, Kendoff D, Gehrke T. How reliable is the alpha-defensin immunoassay test for diagnosing periprosthetic joint infection? A prospective study. Clin Orthop Relat Res. 2017;475(2):408-15.
41. Ritter SY, Subbaiah R, Bebek G, Crish J, Scanzello CR, Krastins B, Sarracino D, Lopez M, Crow MK, Aigner T, Goldring MB, Goldring SR, Lee DM, Gobezie R, Aliprantis AO. Proteomic analysis of synovial fluid from the osteoarthritic knee: comparison with transcriptome analyses of joint tissues. Arthritis Rheum. 2013;65(4):981-92.

42. Liao YS, McKellopa H, Lua Z, Campbellb P, Benyaa P. The effect of frictional heating and forced cooling on the serum lubricant and wear of UHMW polyethylene cups against cobaltchromium and zirconia balls. Biomaterials. 2003;24(18):3047-59.

43. Fang HW, Shih ML, Zhao JH, Huang HT, Lin HY, Liu HL, Chang $\mathrm{CH}$, Yang $\mathrm{CB}$, Liu HC. Association of polyethylene friction and thermal unfolding of interfacial albumin molecules. Appl Surf Sci. 2007;253:6896-904.

44. Bagger HL, Ogendal LH, Westh P. Solute effects on the irreversible aggregation of serum albumin. Biophys Chem. 2007;130(1-2):17-25.

45. Behbehani GR, Divsalar A, Saboury AA, Faridbod F, Ganjali MR. A high performance method for thermodynamic study on the binding of human serum albumin with erbium chloride. J Therm Anal Calorim. 2009;96(2):663-8.

46. Singh S, Singh J. Effect of polyols on the conformational stability and biological activity of a model protein lysozyme. AAPS PharmSciTech. 2003;4(3):101-9.

47. Ahrer K, Buchacher A, Iberer G, Jungbauer A. Thermodynamic stability and formation of aggregates of human immunoglobulin $\mathrm{G}$ characterised by differential scanning calorimetry and dynamic light scattering. J Biochem Biophys Methods. 2006;66(1-3):73-86.

48. Singh A, Corvelli M, Unterman SA, Wepasnick KA, McDonnell $\mathrm{P}$, Elisseeff JH. Enhanced lubrication on tissue and biomaterial surfaces through peptide-mediated binding of hyaluronic acid. Nat Mater. 2014;13:988-95.

49. Corvelli M, Che B, Saeui C, Singh A, Elisseeff J. Biodynamic performance of hyaluronic acid versus synovial fluid of the knee for osteoarthritic therapy. Methods. 2015;84:90-8.

Publisher's Note Springer Nature remains neutral with regard to jurisdictional claims in published maps and institutional affiliations. 